\title{
PROTECTION OF INVENTIONS AND KNOW-HOW IN THE COMMON MARKET
}

\author{
J. Gibson SemMes*
}

In the area of industrial rights, an appreciation of the differences between patent, know-how, trademark, and copyright is important to an understanding of the right of territorial protection. A trademark may be defined as a symbol, word, or slogan which is indicative of goodwill and its source. Copyright is generally understood to preserve rights in literary property, which would include works of art, musical compositions, publications, and so on. As between the patentable invention and know-how, it has been said that the patent is a higher order of know-how. Webster has defined invention as the power to conceive and present new combinations of facts or ideas. But patentable invention is in fact that which may be recognized by and registered with a governmental authority. Know-how, on the other hand, is generally thought of as the "combinations of facts or ideas" which enable one to make an invention operational. Although know-how does not usually rise to the dignity of invention, the law increasingly has recognized the often superior knowledge attributed to know-how. ${ }^{1}$

Know-how is frequently more readily marketable than recognized invention, although attempts to protect it are quite often more easily circumvented because the protections have not been carefully defined or documented. Admittedly, knowhow is more difficult to protect as it encompasses training of personnel; engineering. and consultant services; and production techniques, which would include specifications, drawings, designs, planning, and construction. But because it is more difficult to protect, more care is required in protecting know-how than in protecting patentable invention, a concern which is discussed more fully below.

\section{I}

\section{Patent Rights in EuRope}

\section{A. Disadvantages of the Present Patent System}

It is extremely expensive to secure patent protection in Europe, for the inventor must file separate patent applications in each of the states of Europe. Each country has its own law of inventorship, and the standards of inventorship vary widely between states. In Germany and Holland, for example, one finds the highest standards of proof of inventorship. Thus, the inventor must be careful not to first seek protection in those countries where the initial standard of invention is a lesser one.

- Member of the firm of Patton, Boggs, Blow, Verrill, Brand \& May, Washington, D.C.

${ }^{1}$ See generally T. Costner, Patent Licensing Transactions $\$ \S$ 5.01-5.05 (I4 Business Organizations -PATENTS, 1971). 
Too early an issuance of a patent in such countries may effectively bar the issuance of a valid patent in another country. In Belgium, Italy, Switzerland, and Austria, the fact of invention is often reserved for judicial decision, while in Great Britain, Germany, and Holland, exhaustive examinations are undertaken. While patents are issued more slowly in these latter countries, the early test of invention has been more comprehensive. ${ }^{2}$ In Germany, in particular, extensive prosecution is required, and acceleration is difficult to achieve.

Of great assistance to the corporation seeking protection of its inventions abroad is the patentability search in the Hague. Such a search is highly desirable where an invention of a "pioneer" nature has been developed. If one initially passes the test of inventorship in the Hague-which may be the seat of the European Patent-then he has passed a greater test of inventorship than he is likely to encounter elsewhere.

Another problem confronting the inventor seeking protection in Europe today is the distinctiveness of the tax laws in the separate states. Compliance with these requires complex interstate bookkeeping. This, coupled with the diverse standards of invention, may make the protection burden intolerable to the foreigner. Yet another disadvantage arises from the fact that improvement patents in Europe often have had no longer life than a basic patent. Fortunately, the new European Patent system will change many of these deficiencies.

\section{B. The New European Patent}

The Paris Convention of 1883 serves as a remarkable precedent for the European Fatent Convention. Almost too years ago the primary industrial nations of the world, which included Russia, Japan, and Germany, met and decided that it was important to jointly recognize a primary date of invention. Thus, if one had created an invention in Japan on April $\mathrm{I}, \mathrm{I883}$, and sought to register it there in that year, he did not have to file abroad until March 3r, r884; the world would recognize his date of invention in Japan.

The European Patent Convention, which commenced in r953, should produce a unification of the patent formalities by the end of $1972 .{ }^{3}$ If the remaining details are settled, there will evolve a single patent which may be derived from a contracting state and be effective in all other states. The subject matter which is patentable under the new system is defined in the Convention." To satisfy the standard of invention of the European Patent, a creation must be novel, have industrial or agricultural usefulness, and involve an inventive step, that is, not be obvious to one skilled in the field in which the invention arises. Other limitations are also found in the Convention. The protection of the new patent does not extend to scientific and mathematical methods; materials occurring in nature; purely aesthetic creations; and schemes, rules, or methods of doing business, performing purely mental acts, or

\footnotetext{
2 See generally i \& 2 Los en Stigter, Manuat Industrial Property (Amsterdam 1972).

${ }^{8}$ See generally Convention for a European System for the Grant of Patents: Second Preliminary Draft, 2 CCH Comm. Mkr. REP. If 5503-5677 (197r) [hereinafter cited as Patent Convention, art. -].

See Patent Convention, arts. 9-ro.
} 
playing games. Methods for the treatment of human and animal bodies by surgery or therapy are excluded, as are diagnostic methods. While there is a strong movement in the United States to secure protection for computer programs, the move is of lesser force abroad and the European patent has not yet been extended to these. Finally, while plant or animal varieties are not patentable, there is an indication that microbiological processes or the products thereof may be included under the patent.

Protection throughout the contracting states will be secured upon the filing of a single application. ${ }^{5}$ Anyone-an individual citizen or an entity-may file the patent application, which consists of a request for the grant, a designation of the contracting state, and a description of the invention with any necessary specifications, claims, and drawings. While the application is to be in the language of the filing state, the patent will appear in either English, French, or German. An examination of and report on the state of the art follows the application. Within eighteen months, a provisional patent, which is judicially enforceable and effective for a term of five years, will be issued. There is an opportunity for others to assert opposition to the patent by filing a request for an examination as to patentability. ${ }^{6}$ If the patent is affirmed, a confirmation patent will issue. The patent will extend for a term of twenty years from the date of publication of the provisional grant. The patent is renewable for one term in accordance with the renewal requirements of the con-

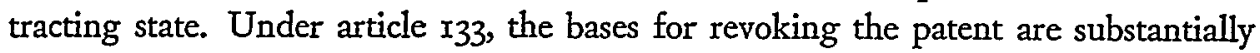
similar to those reflected in the concept of invalidity in the United States. Thus, if someone proves his prior right to the grant or non-inventiveness, the European patent may fail.

When granted, the patent secures to the holder an exclusive right to use his invention in each contracting state and thus permits him to secure compensation for another's unauthorized use. The patent may be licensed for use in all or some of the contractin'g states. Indeed, as in many European countries, licensing or use of the patent may be required within three years of the grant so as to encourage activity under the patent. A license must be recorded, and the European Commission will examine it carefully to determine whether it is in compliance with the Rome Treaty, particularly articles 85 and 86 .

II

\section{Licensing Industrial Rights}

The American firm contemplating licensing its industrial rights abroad will likely encounter very receptive markets. The product standards of the United States are generally recognized as the highest in the world. A prospective licensee will be attracted by the opportunity to minimize the attention which he must devote to quality control by taking advantage of U.S. know-how. In addition, many U.S.

\footnotetext{
${ }^{5}$ See Patent Convention, arts. I8, 19, 85.

- See Patent Convention, arts. IoI-I66.
} 
trademarks are internationally recognized, so that the licensee may be able to further develop his markets on the basis of the licensor's pre-established goodwill. It must be accepted, however, that licensing may not be desirable or feasible in a number of situations. Additional labor and materials costs abroad may exceed the tariffs which would be encountered in direct exportation from this country. In addition, the owner of industrial rights must be concerned about his capacity to control the use of his properties abroad. Finally, of course, the prospective licensor may find that superior product lines have already been established in Europe or that his product is not suitable for use there.

\section{A. Drafting Licensing Agreements}

Once the decision to license has been made, a number of limitations must be observed in structuring the arrangement under which rights are to be transferred.? Many of these are well-known and need be mentioned only briefly. "Package licensing"- the conditioning of the license of one patent on the licensing of anothermay be deemed illegal because its effect is to increase the price of the license to the user and, hence, the cost of the product to the consumer. Licenses should, therefore, be confined to the patent covering the particular product which is to be promoted. Also, the licensee must not be prevented from contesting the validity of the licensor's product. Nor may the licensor prevent the licensee from exporting to the United States. Further, in structuring his royalty arrangement, the licensor must avoid discrimination among competing foreign customers. Finally, the licensor will have an interest in the disposition made of patents on improvements in his product and may desire to include a grant back provision in his license. The U.S. Justice Department will scrutinize such arran'gements, and it is advisable to provide that the grant back will be non-exclusive. ${ }^{8}$

The distinctions between the various types of industrial property outlined above deserve particular consideration in the drafting of a license agreement. The licensor should be careful to separate the licensee's patent rights from those pertaining to know-how and trademarks. ${ }^{9}$ If grants of patent and know-how rights are included in a single agreement, the licensor runs the risk that a breach by the licensee under one of these will affect the grantor's position with respect to the other. In the absence of a separate agreement, a default by the licensee in practising know-how, for example, may mean that the licensor will lose the income that would have come from continued use of the patent. Furthermore, if a trademark is made part of a basic patent and know-how agreement, a licensor may encounter difficulty in preventing a licensee from continuing to use the mark after a default or expiration of

\footnotetext{
${ }^{7}$ See generally Kittler, Current State of Patent and Know-How Licensing, 27 Business Lawyen 69x (1972).

${ }^{8}$ See generally Aluminum Co. of America v. Sperry Prod., Inc., I71 F. Supp. 901,937 (N.D. Ohio I959), aff'd in part \& rev'd. in part, 285 F.2d 9II (6th Cir. 1960), cert. denied, 368 U.S. 890 (196r) (the issue of grant backs was not discussed by the circuit court).

${ }^{\circ}$ See T. COSTNER, supra note $\mathrm{I}$, at $\$ 5.01[2][\mathrm{e}]$.
} 
the patent. From the perspective of the licensor, it is most important that a defaulting licensee not continue to use a famous mark while performing substandard services or producing inferior products.

A typical licensing contract consists of a Master Agreement which contains production know-how rights and refers to a separate agreement as to patent rights and another agreement concerning trademark rights. Because know-how is typically the primary industrial right, the Master Agreement should usually allocate to know-how a royalty reflecting the largest percentage of income from the sale of the product. Patent rights will usually command a lesser portion of the income, and an even smaller percentage should be allocated to the trademark rights. In particular cases, of course, the relative value of the industrial rights may require a different allocation.

A licensing agreement may properly reserve to the grantee discretion in timing the entry of the product into the market since the licensee is likely to have a more complete knowledge of the potential market and clientele. A typical provision in this regard might read:

It is recognized by the licensor that entry into the markets of the various countries of the franchise territory, the timing, the manner and the method of doing same are matters of business judgment and reserved to the licensee.

Exhaustive documentation is important in the effective preservation of know-how right. Although such an undertaking is admittedly difficult in many situations, the licensor should attempt to specify in detail what the licensee's know-how rights will be. If, for example, the know-how relates to a production technique, a full definition of all aspects of the process should be annexed to the agreement. This would include specifications, drawings, and designs as well as material relating to construction planning, the training of personnel, and the like. It is also desirable to include in the agreement a statement about the licensee's obligation with respect to the confidentiality of the material conveyed. Such a statement might read:

The information contained herein is proprietary and is disclosed pursuant to Agreement, comprises consideration thereof and is to be used for purposes of practice thereunder. Licensee agrees to treat the information as confidential and agrees to return it in its original form upon termination of the agreement, for whatever purpose.

While such a provision is, of course, no guarantee against abuse, it does serve to underscore the licensor's interest in preserving his rights and put the onus on' the licensee to preserve the confidential relationship as to trade secrets.

In most licensing situations, careful supervision by the licensor is the key to successful implementation of an industrial rights contract. Thus, in order to preserve the integrity of its trademark, the licensor should specifically reserve the right to supervise the work of the licensee. When the licensor sends its employees abroad to supervise the implementation of a licensing agreement, it is advisable for the business to pay for the services performed. If there is innovation during the installation and 
manufacturing stages, the licensor will be in a better position to preserve his right to those developments.

The licensing agreement should give attention to the parties' responsibility with respect to another's infringement upon the rights which are granted. It is usually desirable for the licensor to reserve to itself the primary responsibility for initiating and pursuing litigation in this regard. If the licensor were to depend on the licensee to sue for infringement, he would, in effect, substantially reduce the amount of control he had over the use of his rights. The licensee's unenthusiastic pursuit of litigation could lead to a substantial diminution of the value of the licensor's properties. With respect to a related matter, it goes without saying that careful selection of a barrister and solicitor to conduct litigation in Europe is essential. American counsel for a domestic licensor should be prepared to involve himself in more than routine supervision of any litigation. Finally, in both litigation and initial license negotiations, American counsel often' overlooks the risks involved in relying upon an interpreter selected by another party. To avoid the difficulties inherent in this situation, the licensor's attorney should directly involve himself in the selection of personal interpreters.

\section{B. Licensing and the Court of Justice}

Several cases decided by the European Court of Justice must be carefully considered by an owner of industrial rights which seeks to license those properties in the Common Market. The basic question which these decisions raise is whether articles 85 and 86 of the Rome Treaty may be applied to weaken the protection which one secures under the presently prevailing concepts of patent, copyright, and trademark rights. Several of these cases are discussed elsewhere in this symposium. ${ }^{10}$ There are, however, a number of principles derived from them which should be emphasized in the present discussion of licensing.

The Court of Justice has attempted to make clear that the ownership of a patent or trademark, and presumably a copyright, is not itself illegal under Articles 85 and 86. The prohibition of those articles will be applied, however, if the rights are used to restrain competition between member states. Under this broad principle, the Court has indicated its strong disfavor of industrial rights arrangements which have the effect of parceling out segments of the market within Common Market countries. This problem is confronted most sharply in situations in which the owner of parallel patents in Common Market states secures from a licensee in one state a coven'ant that he will not export the product to other member countries. In x968, the Court of Justice stated in the Parke-Davis case that:

An enterprise which, on the basis of parallel patents, had granted licenses in various Member States and was using its rights under such patents to prevent trade in

${ }^{10}$ See Timberg, Antitrust in the Common Market: Innovation and Surprise, 37 Law \& Contemp. Prop. 329 ( 1972 ). 
the patented products between the Member States concerned could violate paragraph $x$ of Article $85 .{ }^{11}$

While the Court did not find a violation on the facts before it, it made clear its intention to scrutinize closely attempts to limit the distribution of goods by territorial limitations. In light of subsequent case developments, it has been suggested that the permissible range of distribution restrictions must be regarded as quite narrow. Neither copyrights nor trademark rights may be asserted to prevent parallel imports from another member state, and with respect to patents, it appears that the existence of patent rights in a member state may be used to prevent imports only if the product was produced by an independent third part an'd if there is no parallel patent in its state of origin. ${ }^{12}$

The Sirena case, ${ }^{13}$ which contributed to these principles, contain's language which serves to underscore the critical stance which the Court of Justice has taken with respect to traditional industrial rights. Sirena, an Italian company, had acquired a license to use the trademark Prep on its own cosmetic cream. An Italian competitor imported a similar product under the same trademark, which was supplied by a German firm holding a license from the same American licensor. When Sirena sued for infringement, the defendant, its Italian competitor, alleged that articles 85 and 86 had been violated by the assignment of the mark to Sirena which permitted it to prevent importation from other countries within the Common Market. The Court confirmed the applicability of the prohibitions of the Rome Treaty. To those who accept the traditional effect of trademark rights, the language of the Court is most surprising:

The exercise of a trademark right is particularly apt to contribute to the partitioning of markets and thus to impair the free movement of goods between States. ${ }^{14}$

Perhaps even more disturbing is the Court's observation about the relative importance of trademarks in the hierarchy of industrial rights:

$[T]$ he trademark right differs from other industrial property rights in that things that are protected by the latter are often of greater importance and greater value than the rights deriving from a trademark. ${ }^{15}$

This conclusion must stand in sharp contrast to the view held by the many American industrialists who feel that their trademark may be the most valuable asset which their firms own.

The case which extended the antitrust provisions of the Rome Treaty to the

\footnotetext{
${ }^{11}$ Parke-Davis \& Co. v. Probel, Reese, Beintema-Interpharm \& Centrafarm Cos., I4 Recueil de la Jurisprudence de la Cour 8r (Cour de Justice de la Communauté européenne) [hereinafter cited as Recueil de la Cour], [Court Decisions 1967-I970 Transfer Binder] $2 \mathrm{CCH}$ Comm. MrT. Rep. If 8054, at 78I8 (1968).

${ }_{12}$ Lieberknecht, Industrial Property Rights and The Rules on Competition, 27 BusINEsS LAwYER 8I8 (1972).

${ }_{18}^{18}$ Sirena S.r.l. v. Eda GmbH, I7 Recueil de la Cour 69, 2 CCH Comm. MRT. REP. I 8Ior (I97I).

14 Id.; 2 CCH COMM. MrT. REP. at jIII.

${ }^{15} I d$.
} 
area of copyright is Deutsche-Grammophon. ${ }^{16}$ Deutsche produced records in Germany and sold them to its subsidiary in France. The latter firm in turn sent the records back to Germany for distribution at a price below that which Deutsche maintained there. In the initial litigation before the German courts, it was contended that under Germany Copyright Law, Deutsche had an exclusive right to distribute its recordings in Germany and that these rights had not been exhausted by the sales to the French subsidiary. When the case was referred to the Court of Justice, that Court held that Deutsche's asserted right to exclusive German distribution was contrary to the notion of a free flow of trade within the Common Market which articles 85 and 86 seek to promote. Some commentators who have considered this decision have concluded that the controversy should have been resolved without resort to the principles of the Treaty. They suggest that under the relevant copyright law, Deutsche may in fact have exhausted its exclusive right of distribution by its shipments to France. ${ }^{17}$ Hence, the Court of Justice could have refused to exercise its jurisdiction and left the matter to be resolved under local copyright law.

\section{Conclusion}

The American attorney who has had experience in seeking protection of industrial rights in Europe must surely be impressed by the significant developments of the past several years. On the on'e hand, the prospect of a European patent should be most attractive. With its advent, protection of invention may be achieved by following steps which bear little resemblance to the complex procedures of the past. The new system will offer an improved standard of invention', safeguards against the grant of trivial patents, and extraterritorial recognition of patent validity. On the other hand, however, the American firm must adjust its licensing practices to reflect the concern of the Court of Justice that industrial rights not be so allocated as to undermine the goal of true economic unity among the states of the Common Market. The American firm may properly be concerned about the effect of the Court's decisions upon traditional assumptions about the nature of industrial rights. But the Court's orientation in' this regard should be viewed in the total context of the political and economic unification of Europe. In that perspective, the judicial development in the antitrust field may be seen as a necessary part of an evaluation which may ultimately yield substantial benefits to the American business firm.

\footnotetext{
${ }^{10}$ Deutsche-Grammophon Gesselschaft mbH v. Merto-SB-Grossmärkte GmbH \& Co. KG, Court de Justice de la Communauté européenne, Case No. 78/70, June 8, 1971, 2 CCH Comm. Mrr. REp. ๆ 8106.

${ }^{17}$ See Ladas, International Trademark Protection: Private Interests and Public Programs, 15 IDEn, the Patent, Trademark \& Copyright J. of Research \& Education 79 (1971).
} 